\title{
ROV study of a giant pockmark on the Gabon continental margin
}

\author{
H. Ondréas ${ }^{1^{*}}$, K. Olu ${ }^{2}$, Y. Fouquet ${ }^{1}$, J. L. Charlou ${ }^{1}$, A. Gay ${ }^{3}$, B. Dennielou ${ }^{1}$, J. P. Donval ${ }^{1}$, A. Fifis $^{2}$, \\ T. Nadalig ${ }^{4}$, P. Cochonat ${ }^{1}$, E. Cauquil ${ }^{5}$, J. F. Bourillet ${ }^{1}$, M. Le Moigne ${ }^{6}$ and M. Sibuet ${ }^{2}$ \\ ${ }^{1}$ Département Géosciences, IFREMER, B.P. 70, 29280 Plouzané, France \\ ${ }^{2}$ Département Environnement Profond, IFREMER, B.P. 70, 29280 Plouzané, France \\ ${ }^{3}$ Laboratoire GTS, place Bataillon, Université Montpellier II, 34095 Montpellier cedex 5, France \\ ${ }^{4}$ Laboratoire de Microbiologie et de Génétique, Université Louis Pasteur, CNRS-FRE 2326, Institut de Botanique, \\ 28 rue Goethe, 67083 Strasbourg cedex, France \\ ${ }^{5}$ TOTAL, 2 place Coupole, 92400 Courbevoie, France \\ ${ }^{6}$ Direction Environnement Littoral, IFREMER, B.P. 21105, 44311 Nantes cedex, France \\ *: Corresponding author : Fax: +33-2-98224549 hondreas@ifremer.fr
}

\begin{abstract}
A giant, 800-m wide pockmark, called Regab, was discovered along the Equatorial African margin at 3160-m water depth and was explored by remote operated vehicle (ROV) as part of the Zaiango (1998-2000) and Biozaire (2001-2003) projects carried out conjointly by TOTAL and a number of French research institutes. A microbathymetric map obtained using the ROV sensors shows that the pockmark actually consists of a cluster of smaller pockmarks aligned N70 along a 15-m deep depression. Methane was recorded all over the pockmark, the highest values along the axis of the depression where massive carbonate crusts and dense seep communities were also found. Several faunal species belong to the Vesicomyidae and Mytilidae bivalve families, as well as to Siboglinidae (Vestimentifera) tubeworms. Preliminary analyses confirm their association with symbiotic bacteria, thus documenting their dependence on fluid seeps. The pockmark appears to be related to an infilled channel, visible on the seismic data $300 \mathrm{~m}$ below the seafloor, which may act as a reservoir for biogenic fluids supplied to the trap from the surrounding sediments.
\end{abstract}

Keywords: Equatorial African margin, Pockmark, Exploration, ROV, Microbathymetric map, Gabon 


\title{
ROV study of a giant pockmark on the Gabon continental margin
}

H. Ondréas, K. Olu, Y. Fouquet, J.L. Charlou, A. Gay, B. Dennielou, J.P. Donval, A. Fifis, T. Nadalig, P. Cochonat, E. Cauquil, J.F. Bourillet, M. Le Moigne, M. Sibuet

H. Ondréas (corresponding author) (e-mail: hondreas@ifremer.fr, Fax: +33-2-98224549), Y. Fouquet, J.L. Charlou, B. Dennielou, J.P. Donval, P. Cochonat, J.F. Bourillet IFREMER, Département Géosciences, B.P. 70, 29280 Plouzané, France K. Olu, A. Fifis, M. Sibuet IFREMER, Département Environnement Profond, B.P. 70, 29280 Plouzané, France A. Gay

Université Montpellier II, Laboratoire GTS, place Bataillon, 34095 Montpellier cedex 5, France T. Nadalig

Université Louis Pasteur, Laboratoire de Microbiologie et de Génétique, CNRS-FRE 2326, Institut de Botanique, 28 rue Goethe, 67083 Strasbourg cedex, France

E. Cauquil

TOTAL, 2 place Coupole, 92400 Courbevoie, France

M. Le Moigne

IFREMER, Direction Environnement Littoral, B.P. 21105, 44311 Nantes cedex, France

\section{Geo-marine Letters}

Received: 8 May 2004

Accepted: January 2005

\begin{abstract}
A giant, 800-m-wide pockmark, called Regab, was discovered along the Equatorial African margin at 3,160-m water depth and was explored by remote operated vehicle (ROV) as part of the Zaiango (1998--2000) and Biozaire (2001--2003) projects carried out conjointly by TOTAL and a number of French research institutes. A microbathymetric map obtained using the ROV sensors shows that the pockmark actually consists of a cluster of smaller pockmarks aligned N70 ${ }^{\circ}$ along a 15 -m-deep depression. Methane was recorded all over the pockmark, the highest values along the axis of the depression where massive carbonate crusts and dense seep communities were also found. Several faunal species belong to the Vesicomyidae and Mytilidae bivalve families, as well as to Siboglinidae (Vestimentifera) tubeworms. Preliminary analyses confirm their association with symbiotic bacteria, thus documenting their dependence on fluid seeps. The pockmark appears to be
\end{abstract}


related to an infilled channel, visible on the seismic data $300 \mathrm{~m}$ below the seafloor, which may act as a reservoir for biogenic fluids supplied to the trap from the surrounding sediments.

\section{Introduction}

Pockmarks are typical bottom features on continental margins, associated with seeps of gases and fluids from the deep subsurface. They have been described from many locations along both passive and active margins, amongst others, the North Sea (Hovland 1981; Hovland et al. 1984), the Scotian Shelf (Josenhans et al. 1978), the West Canadian shelf (Fader 1991), the Gulf of Mexico (Sieck 1975), the Gulf of Maine (Scanlon and Knebel 1989; Kelley et al. 1994) and the West African margin (Kasten et al. 2001). Fleischer et al. (2001), Judd (2003) and Mazuenko and Soloviev (2003) have provided reviews of the occurrence of free gas and associated features in the world's oceans. In addition, the increasing deployment of remote operated vehicles (ROVs) and submersibles in recent years has facilitated the collection of ground-truth data on such seepages (Orange et al. 1999;

Eichbubl et al. 2000; Coleman and Ballard 2001; Orange et al. 2002; Paull et al. 2002; Dimitrov and Woodside 2003).

Pockmarks are often circular but, where bottom tidal currents are present, they can be elongated and oriented in a preferred direction (Josenhans et al. 1978; Boe et al. 1998). Their diameters can vary in the range 10s--100s m, for example, $<100$ m on the Scotian Shelf (King and MacLean 1970; Josenhans et al. 1978), 10--300 m in Penobscot Bay (Scanlon and Knebel 1989) and on the Norwegian Trench slope (Boe et al. 1998), and 350 m in Belfast Bay (Kelley et al. 1994). Cole et al. (2000) described a cluster of Palaeogene subsurface pockmarks in the UK sector of the North Sea, with craters reaching $4 \mathrm{~km}$ in diameter. The depths of pockmarks vary from 5--10 m (King and MacLean 1970; Josenhans et al. 1978) to $45 \mathrm{~m}$ (Boe et al. 1998).

Methane-dependent fauna and bacterial mats are often associated with active seepages. These had initially been described from very different geological settings, such as the Gulf of Mexico passive margin (Paull et al. 1984) where seep ecosystems have been intensively studied by MacDonald et al. (1990, 2003), Nix et al. (1995), Fisher et al. (1997, 2000) and Berquist et al. (2003a, 2003b), the Oregon coast subduction zones (Suess et al. 1985), and the Japan trenches (Laubier et al. 1986; Sibuet et al. 1988). To date, more than 20 seep areas colonized by benthic communities relying on microbial chemosynthetic production have been described worldwide (Sibuet and Olu 1998; Sibuet and Olu-Le Roy 2002). Although methane is generally the major component of the emitted fluid, sulphide produced near the surface can also serve as an energy source for chemoautotrophic bacteria living either free in the sediment or in symbiosis with invertebrate fauna. Sulphide production in the sediment is by sulphate-reducing bacteria living either free or associated with methane-consuming archae (Boetius et al. 2000). 
Pockmarks were first described as "cone-shaped depressions possibly formed by either ascending gas or subsurface water leakage from underlying sediments” (King and MacLean 1970). This formation theory, involving "gas turbation lifting the fine sediments into suspension", is now generally accepted (Josenhans et al. 1978). Catastrophic events involving earthquakes (Fader 1991), tsunamis or major storm waves have also been invoked to explain the formation of pockmarks (Kelley et al. 1994). The cold fluids seeping from pockmarks consist of water and/or liquid or gas hydrocarbons. Gas hydrates can also be formed when gas supplies are sufficient and when appropriate pressure--temperature conditions allow water and gas to combine.

Pockmark fluids have two primary origins: (1) methane is produced by methanogenic bacteria (biogenic gas) located inside the sediments, from where it migrates to the seafloor entrained in pore water (Kelley et al. 1994); in this case, the chemical composition of the fluid is governed by the decomposition of marine organic material, the conditions of formation (cf. type of organic material, heat, pressure, microbial diversity, burial duration) determining its nature; (2) hydrocarbon gas is produced by the thermal alteration of sedimentary organic matter (cf. thermogenic gas; Hovland and Judd 1988; Fader 1991).

The migration of fluids contributes to methane production by concentrating gas hydrates in the sediment. The understanding of gas migration through the sediment cover can help to underpin the hydromechanical behaviour of this layer, especially in relation to slope instability. Thus, the study of cold seeps is of major interest in assessing geological and sedimentological processes along continental margins.

In 1998, IFREMER and TOTAL started a joint scientific project named Zaiango dedicated to the geological exploration of a large area of the Gabon-Congo-Angola margin, near the Zaire deep-sea fan (Fig. 1a). The main objectives of the Zaiango project were to obtain a cartographic map of the Zaire deep-sea fan (Savoye et al. 2000) and to study the deep margin structure, slope stability and related gas hydrates. The research project also included a complete survey of fluid vents at different spatial scales. This was followed by the Biozaire project initiated in 2001, which aimed at understanding deep-sea ecosystems driven by different energy sources on the Gabon-Congo-Angola continental margin and near the Zaire channel.

\section{Geological setting}

The passive Gabon-Congo-Angola margin was formed by the break-up of South America and Africa some 140 Ma ago during the early Cretaceous, associated with the opening of the South Atlantic Ocean. The post-rift sedimentary sequence of the southern Gabon margin consists of (1) 
aggradation of siliceous and clastic deposits during Aptian--Eocene times, corresponding to a period of long and continuous post-rift thermal subsidence of the platform, and (2) progradation of silty-sand turbiditic sediments from the Miocene to present times (Séranne et al. 1992).

The two sedimentary sequences are separated by a major Oligocene erosional unconformity. During the initial stage of seafloor spreading (Aptian), evaporites were deposited in the young ocean north of the Walvis Ridge, sealing the syn-rift depositional sequence comprising Neocomian--Barremian lacustrine to fluvial clastics and shales rich in organic matter (Roberts and Yapaudjian 1990).

Besides local variations, the Congo-Angola margin displays a first-order architecture similar to that of the southern Gabon margin. A combination of recent seismic reflection and refraction data (Moulin et al. 2002) shows, from east to west, a domain of 30-km-thick continental crust, a domain where the crust thins from 30 to less than $7 \mathrm{~km}$, a transitional domain with $6 \mathrm{~km}$ of crustal thickness, and a post-rift sedimentary cover reaching less than $8 \mathrm{~km}$.

During the Zairov cruise and the Biozaire I cruise in 2000 and 2001 respectively (Sibuet et al. 2002, 2003), Victor ROV dives were carried out over a variety of geological structures along the GabonCongo-Angola margin (Fig. 1a). Different types of pockmarks and associated fauna were observed and sampled. The giant Regab pockmark (Regab is the name of a local beer), reported in the present study, is located over oceanic crust (cf. above; M. Moulin, personal communication). Preliminary analyses of gas hydrates recovered at the eastern boundary of this pockmark on the Gabon margin (cf. core KZR-42) show that methane is the major chemical component of the emitted fluids (Charlou et al. 2004).

The sedimentological setting of the Regab pockmark is unusual because of proximity to the huge detrital sedimentary system of the Zaire deep-sea fan, being located less than $10 \mathrm{~km}$ north of the active Zaire submarine channel (Fig. 1b, d). The pelagic sediments covering the Zaire deep-sea fan comprise stacked buried channel-levee systems. The Regab feature is rather isolated, since only one other, smaller pockmark occurs a few kilometres to the north. These two pockmarks are located in an area where sedimentation rates can reach 10--20 cm/1,000 years (B. Dennielou, personal communication), and where few fluid escape features have been observed (Kasten et al. 2001; Gay et al. 2003).

\section{Materials and methods}

The Regab site was investigated by means of a Simrad EM12 seafloor imaging system, as well as echosounder ( $3.5 \mathrm{kHz}$ ) and two-dimensional high-resolution seismic profiling (Zaiango 1 and Zaiango 2 cruises, 1998, RV l'Atalante).

Photographs and videos had been collected across the pockmark during a tow-fish survey (Zaicar cruise, April 2000, RV Le Suroit; chief scientist, J.F. Bourillet) revealing the presence of a very 
abundant and typical cold seep-related. The various seafloor features (fluid expulsions, biological communities and precipitates) were subsequently investigated in more detail in the course of dives using the ROV Victor from aboard the RV l'Atalante.

Two ROV dives (nos. 14 and 15) were dedicated to the collection of ten 100-m-long, regularly spaced video transects (Fig. 2) during the Zairov cruise, (December 2000, RV l'Atalante). The video survey was completed during the Biozaire I cruise (January 2001, RV l'Atalante), and faunal sampling was carried out to obtain more detailed information about the biological communities and spatial distribution of the fauna at the Regab site (Olu-Le Roy et al. 2001).

During the systematic ROV survey of the Regab pockmark, geochemical tracers were used to detect fluid seep sites. Nineteen mini-sampler bottles (volume of $200 \mathrm{ml}$ each) were deployed 2--3 m above the bottom to collect water samples for methane measurements. These samples were analysed on board ship using a chromatographic-purge/trap technique (Charlou and Donval 1993). In addition, massive carbonate crusts were sampled by means of the ROV manipulator arm, powdered in an agate mortar and analysed by X-ray diffraction using an XRD Bruker D500 analyser with a $\mathrm{Cu} \mathrm{X}$-ray tube for mineral composition, and by X-ray fluorescence using a WDXRF Siemens SRS303 analyser for major and trace element composition.

Sediment collected by the ROV cores (length of $400 \mathrm{~mm}$ each), were sampled each centimetre and analysed by X-ray diffraction.

The ADELIE software, developed at IFREMER, was used to process the ROV data. This postprocessing software is based on a geographical information system (GIS), and serves to filter/smoothen data on vehicle navigation (cf. direction, speed), to visualize and enhance images and videos (cf. camera orientation, etc.), and to process datasets on, amongst other things, water pressure and temperature. Vehicle elevation above the seafloor and vehicle depth below the sea surface were added in order to obtain highly accurate values of water depth at each navigation point along the ROV tracks (Dives 14 and 15, Zairov cruise; Dive 81 and 82, Biozaire I cruise). By interpolation based on the fixed radius method, it was possible to generate a "microbathymetric" map of the pockmark area.

In December 2000, three vertical CTD/rosette casts were carried out from aboard the RV l'Atalante during the Zairov cruise (Fig. 2). The first was located in the centre of the pockmark (BZR07), the second $200 \mathrm{~m}$ to the west (BZR05), and the third $1 \mathrm{~km}$ to the southwest (BZR06). These casts were able to constrain a 200-m-thick water layer located above the seafloor.

In 1998 during cruise Zaiango 2 aboard the RV l'Atalante, two gravity cores were taken in the centre (core KZ2-17, 12 m long; Fig. 2), and 1 km away from the pockmark (core KZ2-18, 12.9 m 
long; Fig. 2). In December 2000, during Zairov cruise aboard the RV l'Atalante, one gravity core was taken at the eastern edge of the pockmark (core KZR-42, $12.3 \mathrm{~m}$ long; Fig. 2). These cores have been opened and described aboard (cf. Results).

\section{Results}

ROV observations and morphology inferred from microbathymetric data

The 800-m-wide, 15--20 m deep Regab pockmark was first observed in 1998 during the Zaiango 1 cruise as a dark spot resulting from strong backscatter on the Simrad EM12 seafloor image (Fig. 1b). The pockmark is located in a deep abyssal setting at a water depth of 3,160 m. It is circular and apparently undisturbed by bottom currents. Echosounder $(3.5 \mathrm{kHz})$ and two-dimensional highresolution seismic profiles provide vertical cross sections of the pockmark showing a 300-m-deep pipe along which gas escapes (Fig. 1c, d). No bottom simulating reflector (BSR) is seen on the seismic profile. The rooting pipe seems to originate in a buried channel. No gas-charged sediments are visible beneath the pockmark along this profile.

The microbathymetric map (Fig. 3) shows a series of small pockmarks each less than $100 \mathrm{~m}$ in diameter, a few metres deep, and aligned ${\mathrm{N} 70^{\circ}}^{\circ}$ in a shallow depression $600 \mathrm{~m}$ long, $200 \mathrm{~m}$ wide and $6 \mathrm{~m}$ deep. The depression seems to be the most active area in terms of fluid escape, strong methane anomalies being concentrated here (cf. Fig. 4).

The area around the pockmark is composed of bioturbated pelagic sediments. Towards the centre, however, patches of white bacterial mats (Fig. 5a), clusters of Vesicomyidae bivalve shells (mainly empty), and spots of black anoxic sediments can be observed (Fig. 5b). Also, massive carbonate crusts (Fig. 5f--h) are associated with live mussels (Fig. 5c) and siboglinid (Vestimentifera) tubeworms (Fig. 5e), and live Vesicomyidae clams occur on the anoxic sediments (Fig. 5d). In the eastern sector of the pockmark, dissociation of solid gas hydrate occurred locally when the sediment was disturbed by the manipulator arm of the ROV (Fig. 4). Pieces of hydrate escaped from the sediments and were lifted into the open water. A bottom simulating reflector (BSR) should be very shallow at this site, as free gas occurs near the surface. Surprisingly, no BSR was observed near the surface on the seismic profile crossing the centre of the pockmark in this area (cf. above).

\section{Lithostratigraphy and sedimentary facies}

Core KZ2-17, collected at 3,161-m water depth in the middle of the Regab pockmark (Fig. 2), shows sediments consisting of dark greenish, nannofossil-bearing siliceous (diatoms and radiolarian) silty clay. A strong hydrogen sulphide smell emanated from the core. In the upper $6 \mathrm{~m}$, bioturbation is pervasive, and intact or broken bivalve shells and carbonate concretions are common. Pockets of liquefied sediment, possibly melted methane hydrate, were observed in the 
lower 6 m (similar to “soupy sediments”; cf. Leg 146 ODP Initial Report, Westbrook et al. 1994). Lobe-shaped or smoke wreath-shaped ichnofacies can be related to fluid circulation.

Core KZ2-18, collected $1 \mathrm{~km}$ north of the pockmark at 3,144-m water depth (Fig. 2), shows that outside the pockmark, the sediments display a similar lithology but with a weaker hydrogen sulphide smell. Fluid vesicles are abundant between 2.30 and $7 \mathrm{~m}$ below the seafloor. Core KZR42, at the eastern boundary of the pockmark at 3,158-m water depth (Fig. 2), shows massive hydrates occurring from the core surface down to a depth of $6 \mathrm{~m}$ (Charlou et al. 2004).

\section{Turbidity and methane distribution}

The ROV CTD/rosette casts reveal the presence of turbidity in deep waters in the whole pockmark area as well as measurable $\mathrm{Mn}, \mathrm{Fe}$ and methane amounts. An increasing of turbidity (measured in voltage) exists close to the centre. Analyses of two CTD/rosette samples collected near the centre of the pockmark show $\mathrm{CH}_{4}$ concentrations of 300--400 nl/l, which is 30--40 times the oceanic background (10 nl/l in the region) (Charlou et al. 2004). The highest $\mathrm{CH}_{4}$ concentrations (128 $\mu \mathrm{l} / \mathrm{l}--$ $224 \mu \mathrm{l} / \mathrm{l}$ ) were detected close to the seafloor in the centre of the pockmark.

ROV water samples reveal methane at several places within the pockmark, showing large variations in concentration (Fig. 4). The lowest concentration is found at the structure periphery $(<1 \mu \mathrm{l} / \mathrm{l})$. The maximum value $(129 \mu \mathrm{l} / \mathrm{l})$, recorded in the centre of the pockmark, is 10,000 times the oceanic background (Charlou et al. 2004). Highest methane values are generally concentrated along the centre line of the $\mathrm{N} 70^{\circ}$ depression visible on the microbathymetric map (Fig. 3). A methane concentration of $16 \mu \mathrm{l} / \mathrm{l}$ was documented at the eastern boundary of the pockmark, in an area where massive gas hydrates were collected. Temperature measurements in the fluid escape areas indicate an increase in local water temperature by $1--2{ }^{\circ} \mathrm{C}$.

Note that these $\mathrm{CH}_{4}$ data serve only as rough assessments of areas of maximum/minimum diffuse discharge, no individual, well-defined focused discharges having been identified.

\section{Carbonate crusts and sediment mineralogy}

In the Regab pockmark, thicker carbonate deposits are concentrated in the central part of the N70 ${ }^{\circ}$ depression (Figs. 3, 5f). These form paving stones of variable thickness ( $\mathrm{cm}$ to $\mathrm{m}$ ) and cover an area of up to a few hundred square metres. Their areal extent was difficult to determine precisely because they were frequently covered by sediments. Thus, only the visible extensions of the crusts are shown in Fig. 3.

Two main types of crusts were identified: (1) carbonate-associated bivalve shells (Fig. 5g), and (2) massive carbonates within the sediments (Fig. 5h). The carbonates which fossilize and cement the shells are composed primarily of calcite and magnesian calcite. The frequent occurrence of 
aragonite relates to shell fragments (mussels or Vesicomyidae) incorporated in the samples. The massive crusts, by contrast, are composed mainly of magnesian calcite, barytine $\left(\mathrm{BaSO}_{4}\right)$ occurring as a trace mineral only.

Carbonates were totally absent in the reduced sediments surrounding the carbonate crusts. In areas of massive hydrates, the sediments are composed mainly of quartz, kaolinite and halloysite, and show highest pyrite and pyrrhotite contents, thus indicating extreme reducing conditions. Millimetre-length magnesian calcite and aragonite granules occur within these sediments. Quartz, kaolinite and smectite are also found in the black anoxic sediments surrounding the carbonate crusts, indicating that these sediments are mainly detrital in origin. Pyrite appears to be related to iron reduction in association with microbial activity.

The sulphur content of the anoxic sediments is very low $(<0.7 \%)$, especially at sites where no crust was observed. By contrast, in or near the sediments containing carbonate crusts, sulphur contents are higher, varying in the range 1.5--3.4\%. The highest sulphur content (3.4\%) was measured in the centre of the pockmark in sediments associated with carbonate crusts, accompanied by the release of methane hydrates and few bubbles. These bubbles, with oily appearance, were only observed at one spot and not sampled. Sulphide levels correlate relatively well with the presence of pyrite. Otherwise, no oil was observed in the sediments or carbonates of the pockmark.

\section{Composition and distribution of chemosynthetic communities}

The Regab pockmark communities (Figs. 5 and 6) are dominated by large invertebrates belonging to families found in most cold-seep ecosystems (Olu-Le Roy et al. 2001) and associated with symbiotic bacteria (Nadalig et al. 2001). They include Vesicomyidae (two undescribed species; Fig. 5d) and Mytilidae (Bathymodiolus sp.) bivalves (Fig. 5c; R. von Cosel, personal communication), as well as siboglinid tubeworms (Vestimentifera, Escarpia southwardae n. sp., Andersen et al. 2004; Fig. 5e).

Video recordings of four dives from the Zairov (dives 14 and 15) and Biozaire I (dives 81 and 82) cruises were used to plot the spatial distribution of these dominant faunal species using the GISbased software Adelie developed at IFREMER (Fig. 6). Mytilids and siboglinids are distributed throughout the central part along the $\mathrm{N}^{\circ} 0^{\circ}$ axis, their distribution appearing to be related to the presence of carbonate concretions and the highest methane concentrations. The siboglinid fields can cover large areas (up to $100 \mathrm{~m}$ long), whereas individual mytilid beds can reach $30 \mathrm{~m}$ in length. Some active vesicomyid beds were observed around the concretions in the central area and in anoxic black sediment, but the two main vesicomyid fields (100 $\mathrm{m}$ long) are located at the east and west edges of the $\mathrm{N}^{\circ} 0^{\circ}$ depression. These large fields include both living and dead patches. Small 
(1 m diameter) clusters of vesicomyids can also be seen in small depressions and in association with anoxic sediments, but they are mainly dead.

\section{Discussion}

Seafloor pockmarks may have several origins, but two have been reported more often than others: 1. Association with explosive release of overpressurized interstitial fluids (liquids and gases). In this case, gas migrates vertically, and the presence of an effective top seal initiates overpressure build-up in the gas-filled sediments, causing the seafloor to dome upwards (Cole et al. 2000). The dome can then fracture and collapse, leading to gas escape (Josenhans et al. 1978; Hovland and Judd 1988).

2. Creation by sedimentological processes such as erosion. On the lower continental slope of California, for instance, no evidence was found for active or past gas or fluid venting in association with the presence of a huge field of 19 pockmarks. This questions the central role of gas in pockmark generation (Paull et al. 2002).

For reasons outlined below, the first hypothesis is evoked to explain the origin of the Regab pockmark. Two main conditions must exist to induce the formation of a pockmark in this case: the presence of a reservoir where fluids are trapped, and the formation of overpressure to expel the trapped fluids. The presence of fluids on the seafloor can be associated with freshwater discharge or result from gas hydrate decomposition in the upper limit of the gas hydrate stability zone. In the latter case, fluids can indicate the possible existence of significant subsurface hydrocarbon accumulations. The gas hydrate stability zone may also play an important role by trapping the fluids above the free-gas zone.

Carbon and hydrogen isotope ratios in methane are well known to be effective for identifying the specific origin of methane (Schoell 1988). At the Regab site, geochemical assessments by Charlou et al. (2004) of the gas hydrate recovered in core KZR-42 (Fig. 2) show two main results:

1. Raman spectroscopy revealed that the gas is composed largely of methane (99.1\%), with minor amounts of $\mathrm{CO}_{2}(0.83 \%)$ and traces of heavier gases such as ethane $(0.043 \%)$, propane, butane and pentane, and $\mathrm{H}_{2} \mathrm{~S}(0.02 \%)$. Raman spectroscopy shows a type I cubic structure.

2. The hydrate methane has a $\delta^{13} \mathrm{C}$ signature of $-69.3 \%$ (PDB) and a $\delta \mathrm{D}$ value of $-199 \%$ (SMOW). A plot of $\delta^{13} \mathrm{C}\left(\mathrm{CH}_{4}\right)$ versus $\delta \mathrm{D}\left(\mathrm{CH}_{4}\right)$ isotopic data suggests bacterial $\mathrm{CO}_{2}$ reduction for the origin of the gas (cf. Whiticar 1999; Charlou et al. 2004).

These findings indicate that, in the Regab pockmark, methane is probably produced in situ in a shallow reservoir, by microbial activity in or below the gas hydrate stability zone, and does not migrate from deeper sediments in the form of thermogenic gas. 
Two main factors need to be considered in estimating overpressure: sedimentation rate and sedimentation thickness, and sedimentation rate together with sediment lithology. According to Gay et al. (2003), a sediment thickness of 130--240 m is required to create sufficient overpressure. A thickness less than $130 \mathrm{~m}$ would not lead to fluid escape, whereas a thickness greater than $240 \mathrm{~m}$ could seal the system. An excess pore pressure would then be required to generate a pockmark. Fluids also need pathways to migrate. Discontinuities which represent potential drains for fluid escapes can be linked to deep structural features such as faults and structural surfaces (Boe et al. 1998; Soter 1999; Eichhubl et al. 2000), diapirs (Taylor et al. 2000) and buried channels. On the lower slope of the Congo basin, a sinuous belt of pockmarks mimics a shallowly buried, meandering channel which acts as a horizontal drain for interstitial fluids (Gay et al. 2003). The two-dimensional high-resolution seismic profile across the Regab pockmark (Fig. 1d) shows a 300$\mathrm{m}$-deep pipe which seems to be rooted in a palaeo-channel. Another pipe is visible $200 \mathrm{~m}$ to the east. This second pipe is also rooted in the palaeo-channel but does not reach the surface. It could represent a former, now inactive fluid seep, or an incipient pathway which has not yet reached the seafloor.

In view of the considerations given above, a near-surface origin of fluids escaping from the Regab pockmark is favoured. The fluids could accumulate in the subsurface palaeo-channel which would act as a shallow reservoir. This palaeo-channel is covered by approximately $300 \mathrm{~m}$ of sediment. The fact that, despite this overburden, fluid venting does occur means that the system is at present not sealed. This interpretation implies that biogenic fluids continue to be expelled from the palaeochannel which, in turn, could mean that such fluids are still being supplied to the trap from the surrounding sediments.

The Regab palaeo-channel forms part of the northern system of Quaternary architecture of the Zaire fan described by Droz et al. (2003). This system comprises six subsystems deposited successively in overlapping depocentres (Marsset et al. 2003), and is estimated to have an age of 540--780 ka. The buried channel linked to the Regab pockmark belongs to the oldest subsystem (T. Marsset, personal communication), suggesting that it may have formed around 780 ka B.P.

The question, therefore, is when did the $\mathrm{N}^{\circ} 0^{\circ}$ axis first appear, and for how long has it been actively venting gas and/or fluid? According to Gay et al. (2003), the Regab pockmark may have become active when the sediment cover above the palaeo-channel reached a thickness of $130 \mathrm{~m}$. Because of the extreme variability in sedimentation rate in this turbiditic environment, it is at this stage difficult to estimate age with any reliability. This could perhaps be achieved on the basis of new data, such as age dating of the carbonate crust and flux monitoring in order to better constrain pockmark duration and activity cycles. 
Carbonate concretions and clusters of large invertebrates are good seafloor indicators of fluid escape (Hovland et al. 1987; Sibuet and Olu 1998; Aloisi et al. 2000; Sibuet and Olu-Le Roy 2002). Authigenic carbonate crusts can form along continental margins in association with cold fluid seepages. The formation of carbonates can be strengthened by the decomposition of gas hydrates. Unlike gas hydrates which are unstable, carbonate minerals can be considered as good indicators of microbial activity, and may thus be used to infer the role and nature of fluids through time. The regab site, located at 3,160-m water depth is well above the carbonate compensation depth (5400m) in the Angola basin (Jansen et al. 1984).

The carbonate ions stem from the bacterial oxidation of methane precipitates in the form of carbonate minerals (calcite, aragonite and dolomite) or from purely physico-chemical reactions (Hovland et al. 1987). Under anoxic conditions, however, the oxidation of methane is a biogeochemical process controlled by microbial activity (Boetius et al. 2000; Aloisi et al. 2000; Pancost et al. 2000).

Strong links can be observed between the geological, biological and physico-chemical characteristics of the Regab site. Highest methane concentrations, massive carbonate crusts reaching several metres in thickness, presence of mytilid and siboglinid faunal assemblages, delimit a preferential escape area in the centre of the pockmark along a $N 70^{\circ}$ axis.

Phylogenetic analyses (based on 16S rDNA) evidenced that the Vesicomyidae and Siboglinidae are associated with sulphide-oxidizing bacteria, whereas the Mytilidae harbour both methanotrophic and sulphide-oxidizing symbionts (Nadalig et al. 2001). Moreover, mean stable isotope values of the carbon $\left(\delta^{13} \mathrm{C}\right)$ of mytilid gills and mantle (respectively $-61,94 \%$ and $-62,49 \%$ ) suggest that this species mainly rely on methane ( K. Olu, personal communication). They also require a hard substratum for larval settlement and are restricted to the central area where these conditions, high level of methane and presence of carbonate crusts, are fulfilled.

Vesicomyids and siboglinids rely on sulphide produced in the sediments but their distribution differs according to the nature of the geological substratum: whereas vesicomyids are partially buried in the sediment, siboglinids need concretion to settle. Finally, the small vesicomyid clusters may indicate extinct fluid escapes. Evidently, the very high spatial variability of the fauna may reflect various chemical environments, substratum variability and/or species succession.

\section{Conclusions}

The giant Regab pockmark on the Gabon continental margin poses a challenge to geologists, geochemists and biologists, and many other pockmarks may exist in the region without having been discovered. A more extensive study of pockmark distribution may help to better understand their 
role in a regional geological/ecological context. This will require a high-resolution approach over very large areas.

The discovery of a very deep, active pockmark area at the Equatorial African margin gives new insights into fluid migration processes, their expulsion on the deep seafloor, and their exploitation by highly specialized chemosynthetic communities. The Regab megafaunal richness appears to be high, and the site may harbour numerous seep-endemic species (shrimps, galatheans, holothurians, actinians, gastropods). Further taxonomic characterization will be necessary to test this hypothesis. 


\section{Acknowledgements}

We thank the officers, crew and technicians of the RV l'Atalante and the ROV Victor for their work and support during the Zairov cruise in December 2000 and the Biozaire I cruise in January 2001. The Zaiango and Biozaire projects form part of an IFREMER-TOTAL partnership. We are also grateful to all other persons involved in the Zaiango and Biozaire projects not referenced here. We acknowledge Martin Hovland and an anonymous reviewer for their very helpful comments on the manuscript. 


\section{References}

Aloisi G, Pierre C, Rouchy JM, Foucher JP, Woodside J, Medinaut Scientific Party (2000)

Methane-related authigenic carbonates of eastern Mediterranean Sea mud volcanoes and their possible relation to gas hydrate destabilisation. EPSL 184:321-338

Andersen A, Hourdez S, Marie B, Jollivet D, Lallier F, Sibuet M (2004) Escarpia southwardae sp. nov., a new species of vestimentiferan tubeworm (Annelida, Siboglinidae) from West-African cold seeps. Can J Zool 82:980-999

Bergquist DC, Andras JP, McNelis T, Howlett S, van Horn MJ, Fisher CR (2003a) Succession in Gulf of Mexico cold seep vestimentiferan aggregations: the importance of spatial variability. P S Z N I Mar Ecol 24:31-44

Bergquist DC, Ward T, Cordes EE, McNelis T, Howlett S, Kosoff R, Hourdez S, Carney RS, Fisher CR (2003b) Community structure of vestimentiferan-generated habitat islands from Gulf of Mexico cold seeps. J Exp Mar Biol Ecol 289:197-222

Boe R, Rise L, Ottesen D (1998) Elongate depressions on the southern slope of the Norwegian Trench (Skagerrak): morphology and evolution. Mar Geol 146:191-203

Boetius A, Ravenschlag K, Schubert GJ, Rickert D, Widdel F, Gieseke A, Amann R, Jorgensen BB, Witte U, Pfannkuche O (2000) A marine microbial consortium apparently mediating anaerobic oxidation of methane. Nature 407:623-626

Charlou JL, Donval JP (1993) Hydrothermal methane venting between $12^{\circ} \mathrm{N}$ and $26^{\circ} \mathrm{N}$ along the Mid-Atlantic Ridge. J Geophys Res 98:9625-9642

Charlou JL, Donval JP, Fouquet Y, Ondréas H, Cochonat P, Levaché D, Poirier Y, Jean-Baptiste P, Fourré E, Chazallon B, Zairov-Leg 2 Scientific Party (2004) Physical and chemical characterization of gas hydrates and associated methane plumes in the Congo-Angola Basin. Chem Geol 205:405425

Cole D, Stewart SA, Cartwright JA (2000) Giant irregular pockmark craters in the Palaeogene of the Outer Moray Firth Basin, UK North Sea. Mar Petrol Geol 17:563-577

Coleman DF, Ballard RD (2001) A highly concentrated region of cold hydrocarbon seeps in the southeastern Mediterranean Sea. Geo-Mar Lett 21:162-167

Dimitrov L, Woodside J (2003) Deep sea pockmark environments in the eastern Mediterranean. Mar Geol 195(1/4):263-276

Droz L, Marsset T, Ondréas H, Lopez M, Savoye B, Spy-Anderson FL (2003) Architecture of an active mud-rich turbidite system: the Zaire fan (Congo-Angola margin southeast Atlantic): results from Zaiango 1 and 2 cruises. AAPG 87(7):1145-1169

Eichhubl P, Greene HG, Naehr T, Maher N (2000) Structural control of fluid flow: offshore fluid seepage in the Santa Barbara Basin, California. J Geochem Explor 69/70:545-549 
Fader GBJ (1991) Gas-related sedimentary features from the eastern Canadian continental shelf. Cont Shelf Res 11:1123-1153

Fisher CR, Urcuyo IA, Simpkins MA, Nix E (1997) Life in the slow lane: growth and longevity of cold-seep vestimentiferans. P S Z N I Mar Ecol 18:83-94

Fisher CR, MacDonald IR, Sassen R, Young CM, Macko SA, Hourdez S, Carney RS, Joye S, McMullin E (2000) Methane ice worms: Hesiocaeca methanicola colonizing fossil fuel reserves. Naturwissenschaften 87:184-187

Fleischer P, Orsi TH, Richardson MD, Anderson AL (2001) Distribution of free gas in marine sediments: a global overview. Geo-Mar Lett 21:103-122

Gay A, Lopez M, Cochonat P, Sultan N, Cauquil E, Brigaud F (2003) Sinuous pockmarks belt as indicator of a shallow buried turbiditic channel on the lower slope of the Congo Basin, West African Margin. Geol Soc Lond Spec Publ 216:173-189

Hovland M (1981) Characteristics of pockmarks in the Norwegian Trench. Mar Geol 39:103-117 Hovland M, Judd AG (1988) Seabed pockmarks and seepages. Impact on geology, biology and marine environment. Graham and Trotman, London

Hovland M, Judd AG, King LH (1984) Characteristic features of pockmarks on the North Sea Floor and Scotian Shelf. Sedimentology 31:471-480

Hovland M, Talbot MR, Qvale H, Olaussen S, Aasberg L (1987) Methane-related carbonate cements in pockmarks of the North Sea. J Sedim Petrol 57(5):881-892

Jansen JHF, Van Weering TCE, Gieles R, Van Iperen J (1984) Middle and Late Quaternary oceanography and climatology of the Zaire-Congo fan and adjacent eastern Angola Basin.

Netherlands J Sea Res 17: 201-249

Josenhans HW, King LH, Fader GB (1978) A side-scan sonar mosaic of pockmarks on the Scotian Shelf. Can J Earth Sci 15:831-841

Judd AG (2003) The global importance and context of methane escape from the seabed. In: Woodside JM, Garrison RE, Moore JC, Kvenvolden KA (eds) Proc 7th Int Conf Gas in Marine Sediments, 7--12 October 2002, Baku, Azerbaijan. Geo-Mar Lett 23(3/4):147-154

Kasten S, Hensen C, Zabel M, Ravenschlag K, Boetius A, Spiess V, Schneider R (2001) Gas hydrates in surface sediments of the Northern Congo Fan -- geochemical and microbiological characterization of the top of the gas hydrate stability zone. In: Abstr Vol EUG XI, 8--12 April 2001, Strasbourg, p 1855

Kelley JT, Dickson SM, Belknap DF, Barngardt WA, Henderson M (1994) Giant sea-bed pockmarks: evidence for gas escape from Belfast Bay, Maine. Geology 22:59-62 King LH, MacLean B (1970) Pockmarks on the Scotian Shelf. Geol Soc Am Bull 81:3141-3148 
Laubier L, Ohta S, Sibuet M (1986) Découverte de communautés animales profondes durant la campagne franco-japonaise Kaiko de plongées dans les fosses de subduction autour du Japon. C R Acad Sci Paris Sér III 303:25-29

MacDonald IR, Reilly JF II, Guinasso NL Jr, Brooks JM, Carney RS, Bryant WA, Bright TJ (1990) Chemosynthetic mussels at a brine-filled pockmark in the northern Gulf of Mexico. Science 248:1096-1099

MacDonald IR, Sager WW, Peccini MB (2003) Gas hydrate and chemosynthetic biota in mounded bathymetry at mid-slope hydrocarbon seeps: Northern Gulf of Mexico. Mar Geol 198:133-158 Marsset T, Droz L, Pichon E, Dennielou B, Babonneau N, Savoye B (2003) Cyclicités dans l'architecture interne du système turbiditique du Zaire. In: Abstr Vol 9ème Congr Français de Sédimentologie, 14--16 October 2003, University of Bordeaux, pp 338-339

Mazurenko LL, Soloviev VA (2003) Worldwide distribution of deep-water fluid venting and potential occurrences of gas hydrate accumulations. In: Woodside JM, Garrison RE, Moore JC, Kvenvolden KA (eds) Proc 7th Int Conf Gas in Marine Sediments, 7--12 October 2002, Baku, Azerbaijan. Geo-Mar Lett 23(3/4):162-176

Moulin M, Contrucci I, Olivet JL, Aslanian D, Géli L, Sibuet JC, Nouze H, Réhault JP, Unternehr P (2002) Deep structures of the Angola margin. In: Abstr Vol Conf European Geophysical Society, 21--26 April 2002, Nice, p 79

Nadalig T, Olu-Le Roy K, Budzinsky H, Cambon-Bonavita MA, Sibuet M (2001) Evidence of chemoautotrophy and characterization of bacterial symbionts of invertebrates at two cold seep sites (Gulf of Guinea). In: Abstr Vol 2nd Int Symp Deep-sea Hydrothermal Vent Biology, 8--12 October 2001, IFREMER, Brest, p 205

Nix ER, Fisher CR, Vodenichar J, Scott KM (1995) Physiological ecology of a mussel with methanotrophic endosymbionts at three hydrocarbon seep sites in the Gulf of Mexico. Mar Biol 122:605-617

Olu-Le Roy K, Cochonat P, Fifis A, Ondréas H, Sibuet M (2001) Spatial distribution of chemosynthetic fauna from video records at a new cold seep site in the Gulf of Guinea. In: Abstr Vol 2nd Int Symp Deep-sea Hydrothermal Vent Biology, 8--12 October 2001, IFREMER, Brest, p 209

Orange DL, Greene HG, Reed D, Martin JB, McHuh CM, Ryan WBF, Maher N, Stakes D, Barry J (1999) Widespread fluid expulsion on a translational continental margin: mud volcanoes, fault zones, headless canyons, and organic-rich substrate in Monterey Bay, California. GSA Bull 111(7):992-1009

Orange DL, Yun J, Maher N, Barry J, Greene G (2002) Tracking California seafloor seeps with bathymetry, backscatter and ROVs. Cont Shelf Res 22(16): 2273-2290 
Pancost RD, Sinninghe Damsté JS, Lint De S, Maarel Van der MJEC, Gottschal JC, Medinaut Scientific Party (2000) Biomarker evidence for widespread anaerobic methane oxidation in mediterranean sediments by a consortium of methanogenic archaea and bacteria. Appl Environ Microbiol 66:1126-1132

Paull CK, Hecker B, Commeau R, Freeman-Lynde RP, Neumann C, Corso WP, Golubic S, Hook JE, Sikes E, Curray J (1984) Biological communities at the Florida escarpment resemble hydrothermal vent taxa. Science 226:965-967

Paull CK, Ussler W, Maher N, Greene HG, Rehder G, Lorenson T, Lee H (2002) Pockmarks off Big Sur, California. Mar Geol 181(4):323-335

Roberts P, Yapaudjian L (1990) Early Cretaceous rift sediments of the Gabon-Congo margin: lithology and organic matter; tectonic and paleogeothermal evolution. J Afr Earth Sci 10:319-330 Savoye B, Cochonat P, Apprioual R, Bain O, Baltzer A, 33 others (2000) Structure et évolution récente de l'éventail turbiditique du Zaïre: premiers résultats scientifiques des missions d'exploration Zaïango 1 et 2 (marge Congo-Angola). C R Acad Sci Terre Planèt 331:211-220 Scanlon KM, Knebel HJ (1989) Pockmarks in the floor of Penobscot Bay, Maine. Geo-Mar Lett 9:53-58

Schoell M (1988) Multiple origins of methane in the earth. Chem Geol 71:1-10 Séranne M, Séguret M, Fauchier M (1992) Seismic super-units and post-rift evolution of the continental passive margin of southern Gabon. Bull Soc Géol Fr 163(2):135-146 Sibuet M, Olu K (1998) Biogeography, biodiversity and fluid dependence of deep-sea cold-seep communities at active and passive margins. Deep-Sea Res II 45:517-567

Sibuet M, Olu-Le Roy K (2002) Cold seep communities on continental margins: Structure and quantitative distribution relative to geological and fluid venting patterns. In: Wefer G, Billett D, Hebbeln D, Jorgensen B, Schlüter M, van Weering T (eds) Ocean margin systems. Springer, Berlin Heidelberg New York, pp 235-251

Sibuet M, Juniper SK, Pautot G (1988) Cold-seep benthic communities in the Japan subduction zones: geological control of community development. J Mar Res 46:333-348

Sibuet M, Galéron J, Khripounoff A, Menot L, Olu-Le Roy K, Durrieu J, Miné J, Caprais JC, Crassous P, Fabri MC, Vangriesheim A, Desneulin J, Savoye B, Cochonat P, Ondréas P, Etoubleau J, Loubrieu B, Dinet A, Von Cosel R (2002) Deep sea ecosystems on the Equatorial African Margin: first results of a pluridisciplinary environmental programme and discovery of chemosynthesis based ecosystem. In: Abstr Vol 6th Int Conf Health, Safety and Environment in Oil and Gas Exploration and Production, 20--22 March 2002, Kuala-Lumpur, Society of Petroleum Engineering, ref SPE 73875 
Sibuet M, Caprais JC, Crassous P, Duperron S, Fabri MC, Fifis A, Galéron J, Khripounoff A, Menot L, Nadalig T, Olu-Le Roy K, Vangriesheim A, Andersen A, Von Cosel R (2003) Rich and complex deep-sea ecosystems on the equatorial African margin: general objectives and results of the Biozaire environmental program. In: Abstr Vol 10th Int Symp Deep-Sea Biology, 25--29 August 2003, University of Oregon, p 39 Sieck HC (1975) Practical application of offshore site hazard surveys. Ocean Eng 15:6-9 Soter S (1999) Macroscopic seismic anomalies and submarine pockmarks in the Corinth-Patras rift, Greece. Tectonophysics 308:275-290

Suess E, Carson B, Ritger SD, Moore JC, Jones ML, Kulm LD, Cochrane GR (1985) Biological communities at vent sites along the subduction zone off Oregon. Bull Biol Soc Washington 6:475484

Taylor MH, Dillon WP, Pecher IA (2000) Trapping and migration of methane associated with the gas hydrate stability zone at the Blake Ridge Diapir: new insights from seismic data. Mar Geol 164:79-89

Westbrook GK, Carson B, Musgrave RJ et al. (1994) Cascadia Margin section 6: Cores In: Suess E, von Huene R (eds) Proc ODP, Initial Reports 146(Pt.I). Ocean Drilling Program, College Station, TX, pp 555-587

Whiticar MJ (1999) Carbon and hydrogen isotope systematics of bacterial formation and oxidation of methane. Chem Geol 161:291-314 
Fig. 1 a Location of the study area on the Congo-Angola margin. b Simrad EM12 image (Zaiango 1, September1998) showing the Regab pockmark as a small round feature of high acoustic backscatter located $10 \mathrm{~km}$ north of the active channel of the Zaire deep-sea fan at a depth of 3,160 $\mathrm{m}$. The dotted line $a--b$ denotes the seismic profile shown in $\mathbf{d}$ (Zaiango 2 cruise, November 1998). c Echosounder (3.5 kHz) profile crossing the pockmark from north to south, showing strong backscatter at the edges of the pockmark (Zaiango 2 cruise, November 1998). d Two-dimensional high-resolution seismic profile across the pockmark structure, revealing its 300-m-deep rooting pipe (Zaiango 2 cruise, November 1998)

Fig. 2 ROV survey tracks (dives 14 and 15, Zairov cruise, December 2000), and location of gravity core sites (KZ2-17 and KZ2-18, Zaiango 2 cruise, November 1998; and KZR-42, Zairov cruise, December 2000) and hydrocasts (Zairov cruise, December 2000)

Fig. 3 Microtopography of the Regab site, deduced on the basis of ROV survey data (isobath: $1 \mathrm{~m}$ ). The red line represents the limit of the carbonate crust. Inset (top right): ROV track chart (dives 14 and 15, Zairov cruise, December 2000; dives 81 and 82, Biozaire I cruise, January 2001) used to compile the map

Fig. 4 Near-bottom methane concentrations (dives 14 and 15, Zairov cruise, December 2000), and occurrence of clathrates (hydrates, Zairov cruise, December 2000, blue stars) and carbonate crust (Zairov cruise, December 2000, yellow) at the Regab site. The red circles represent ROV nearbottom water sampling stations, each accompanied by values of methane concentration (after Charlou et al. 2004). The microbathymetry is also shown (isobath: $1 \mathrm{~m}$ )

Fig. 5a--h Biological communities and carbonate crusts at the Regab site (Zairov cruise, December 2000; Biozaire I cruise, January 2001). a Bacterial mat with some bivalve shells (photographed area: 3x2.5 m). b Area of anoxic sediment with bivalves (photographed area: ca. 3x4 m). c Vesicomyidae, holothurians and shrimps (shrimp size: $5 \mathrm{~cm}$ ). d Mytilidae (Bathymodiolus sp.) attached to the top of vestimentiferans (mussel size: $10 \mathrm{~cm}$ ). e Vestimentifera (Escarpia southwardae n. sp.; vestimentiferan height: 2 m). f Massive in situ carbonate crusts colonized by Vestimentifera (length of ROV manipulator arm: $40 \mathrm{~cm}$ ). g Typical carbonate crust sample collected by the ROV, showing an accumulation of partly fossilized bivalve shells cemented by Mg-calcite (scale: $3 \mathrm{~cm}$ in length). $\mathbf{h}$ Massive carbonates formed within the sediment at the seafloor near the occurrence of hydrate (scale: $3 \mathrm{~cm}$ in length) 
Fig. 6 Distribution of the three dominant faunal families found in the Regab pockmark:

Vesicomyidae, Mytilidae and Vestimentifera (dives 14 and 15, Zairov cruise, December 2000;

dives 81 and 82, Biozaire I cruise, January 2001) 


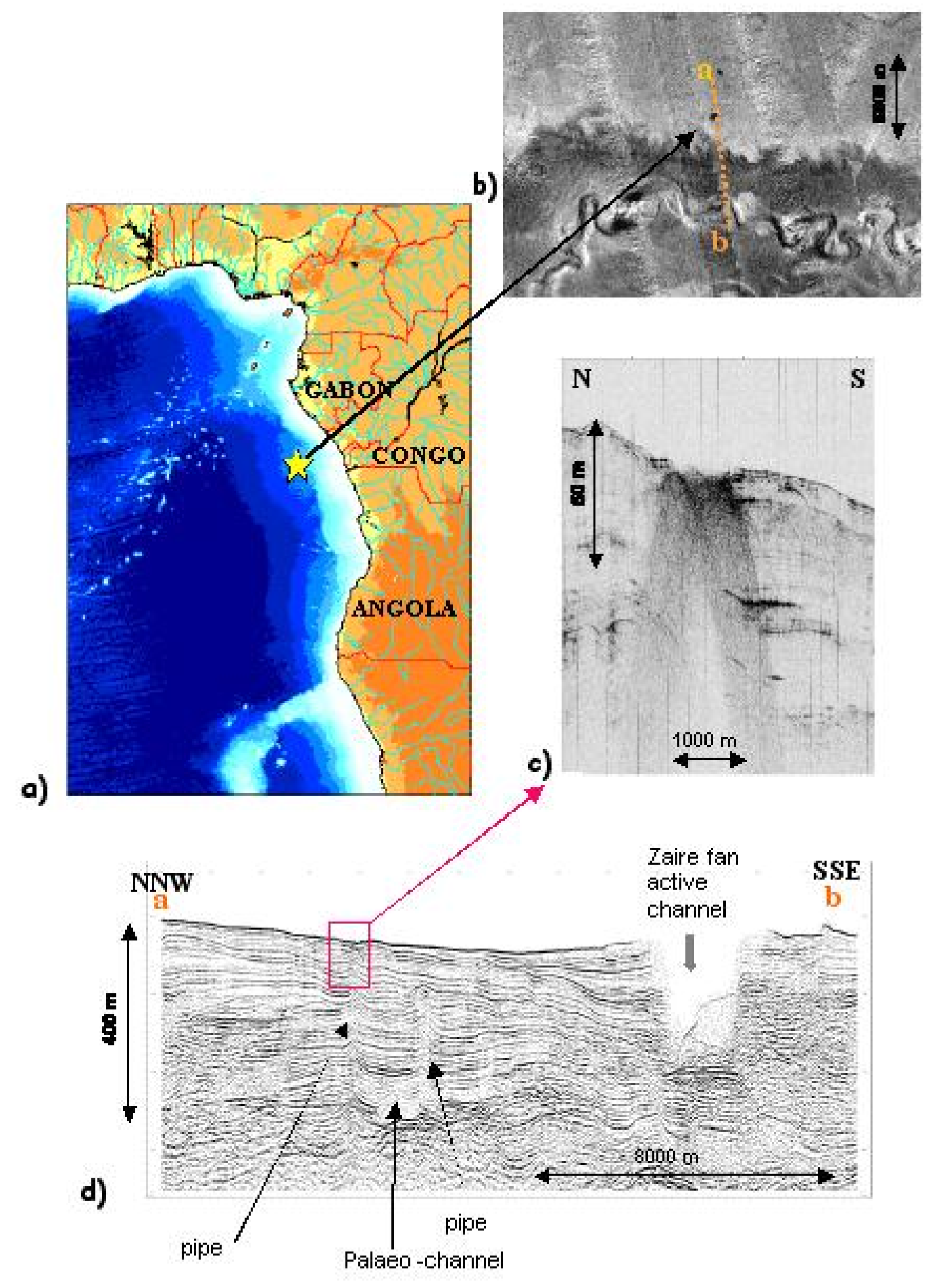

Figure 1 


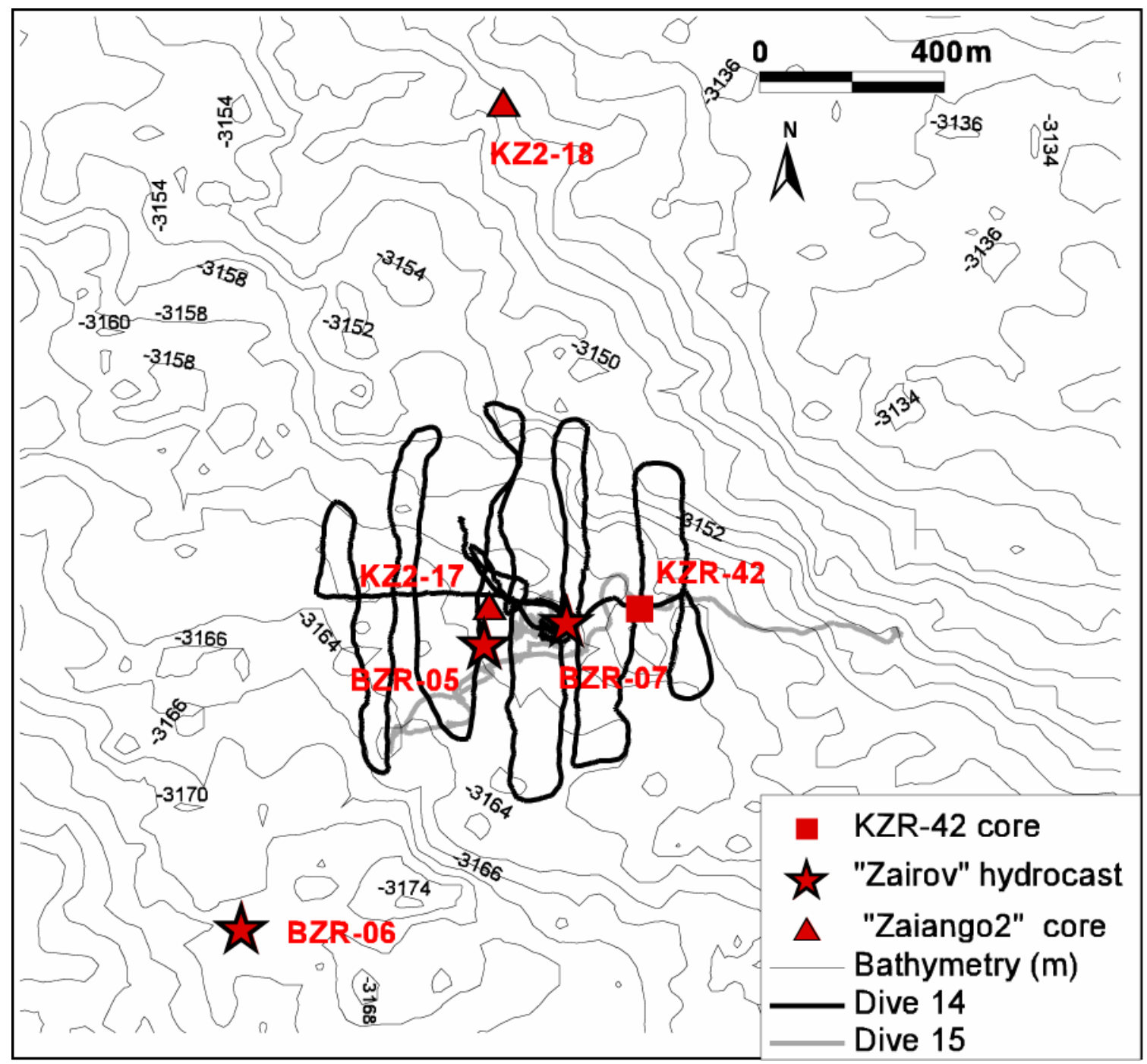

Figure 2 


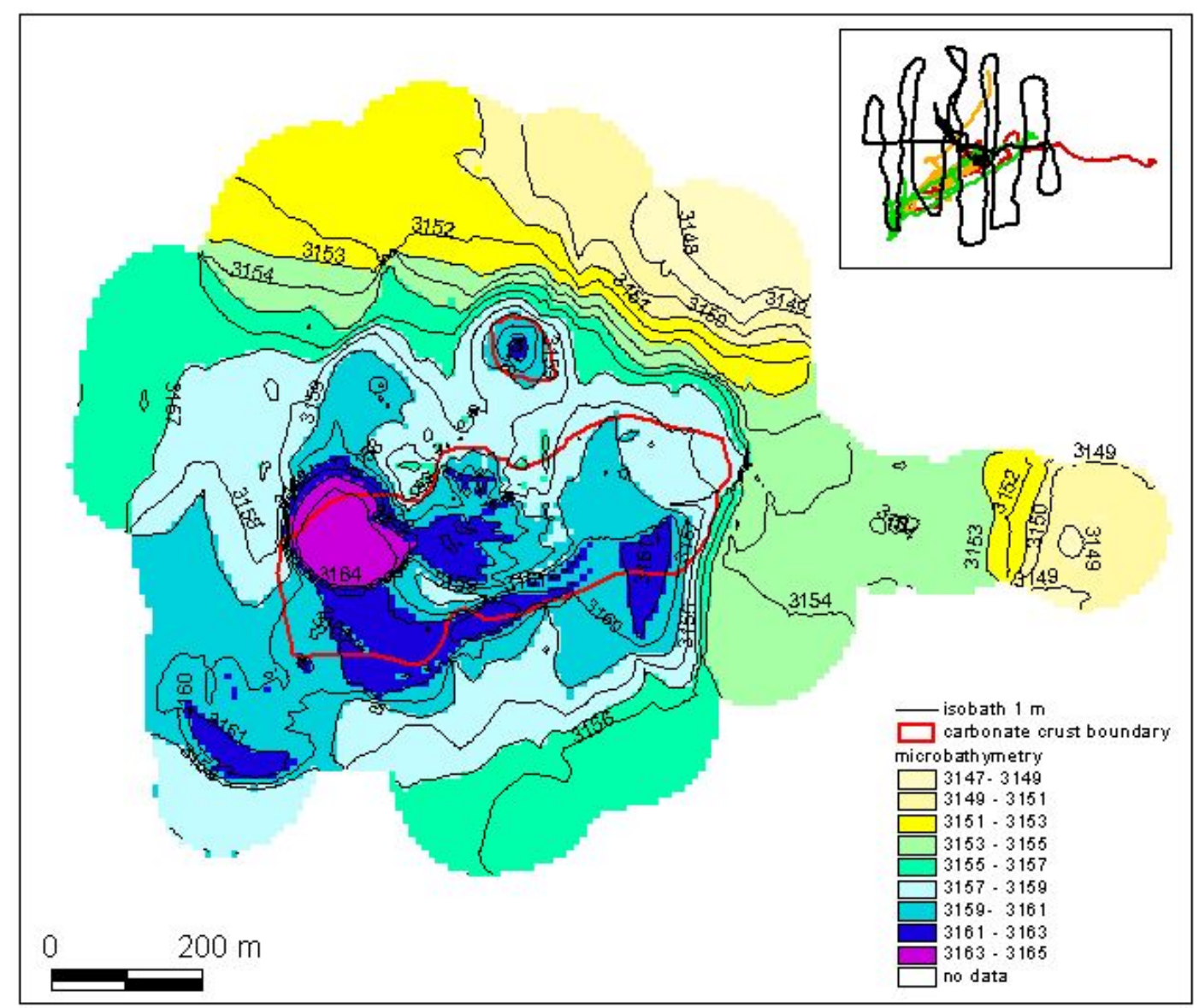

Figure 3 


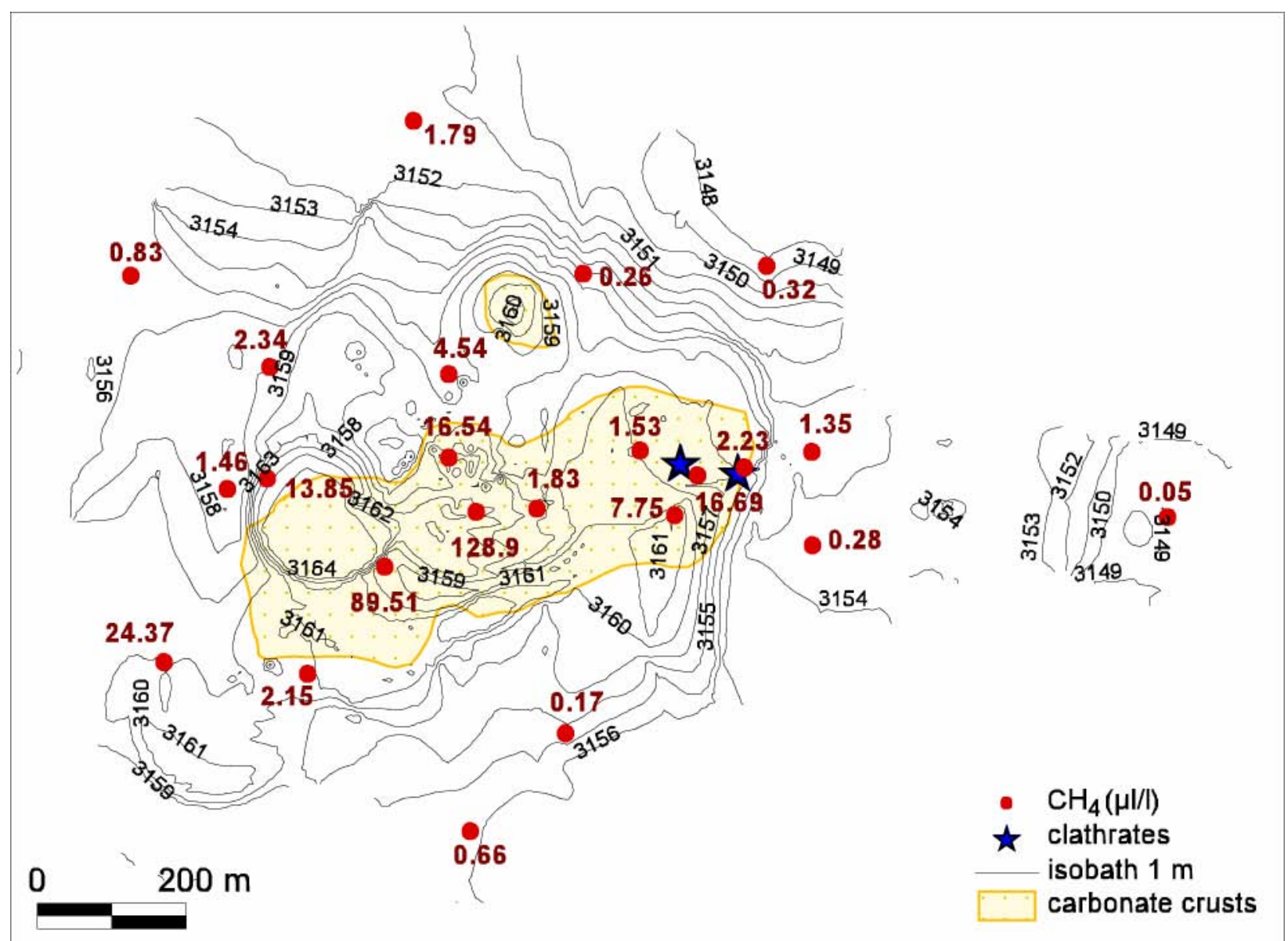

Figure 4 

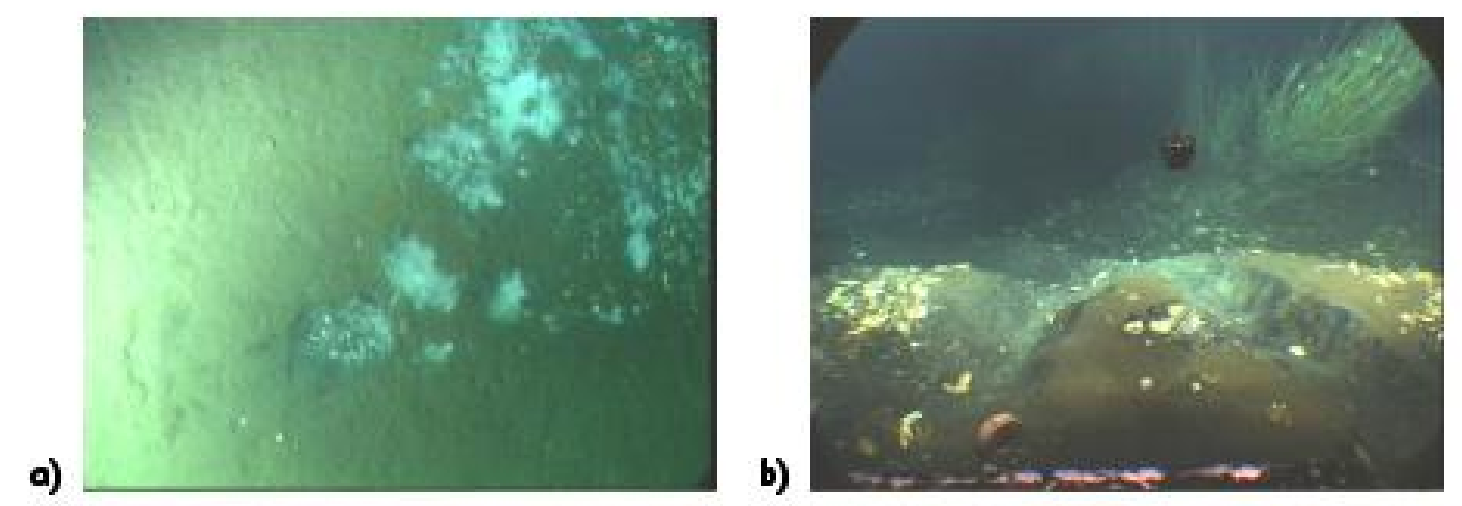

c)
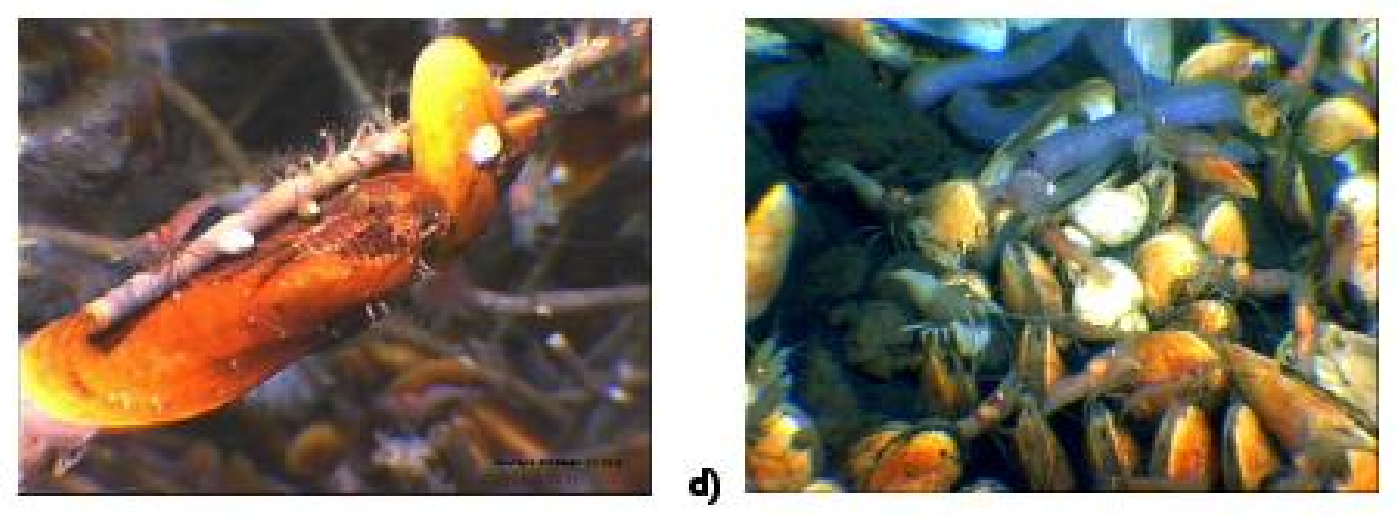

c)
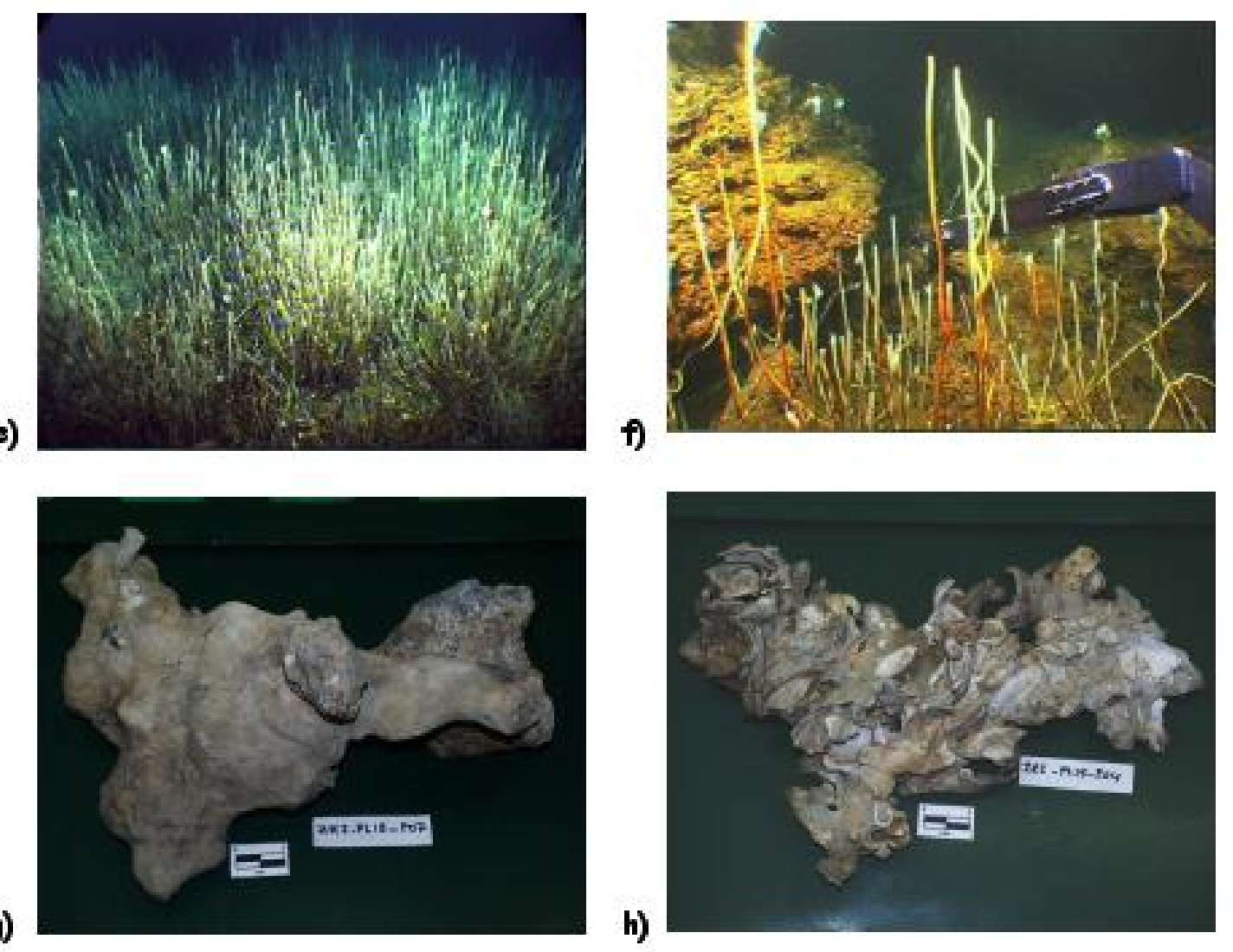

Figure 5 


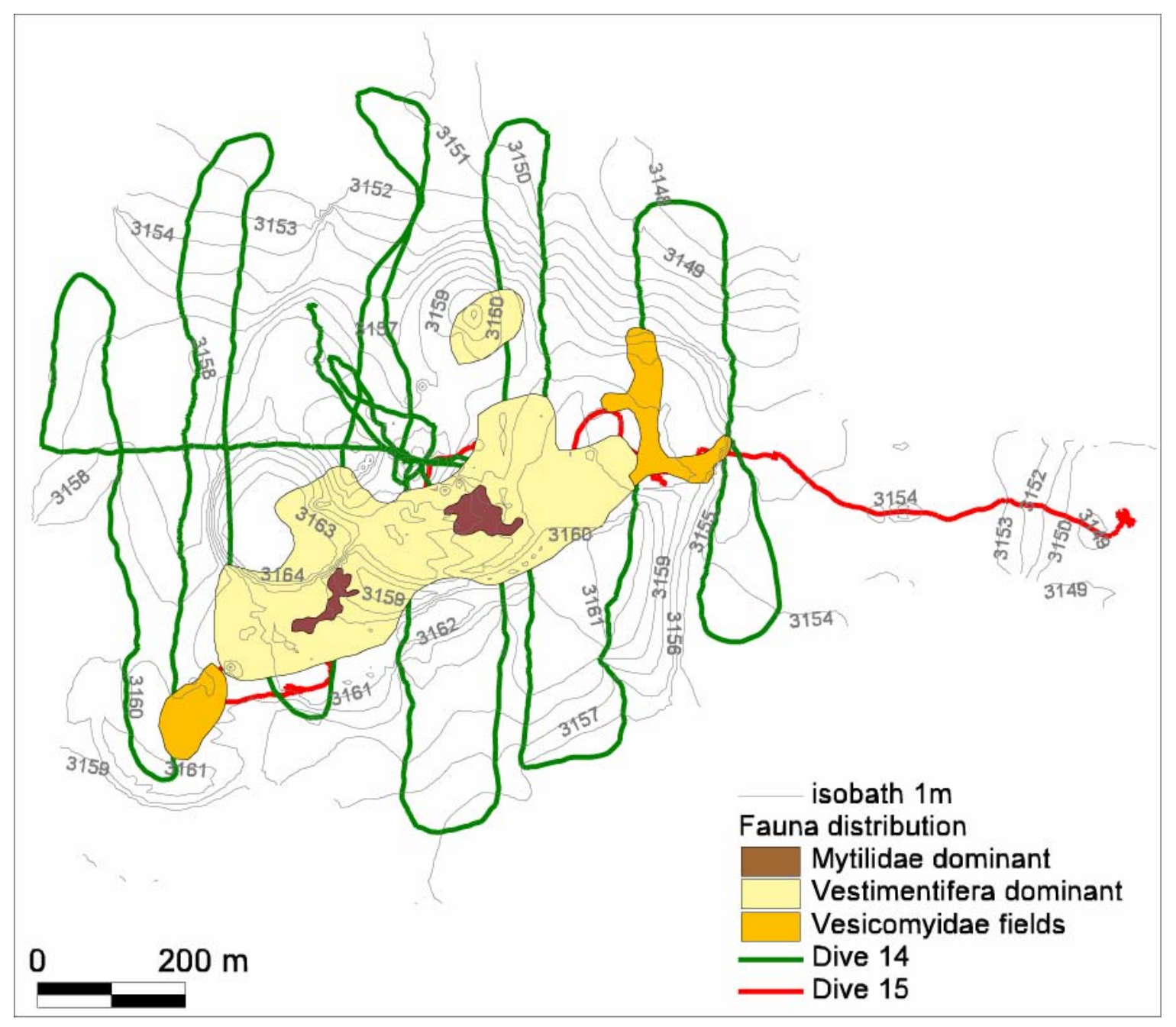

Figure 6 